\title{
Does Unconventional Monetary Policy Affect Bank Profitability in the Euro Area?
}

\author{
Paolo Agnese ${ }^{1,2} \&$ Paolo Capuano ${ }^{2}$ \\ ${ }^{1}$ UNINETTUNO University, Rome, Italy \\ ${ }^{2}$ LUMSA University, Rome, Italy \\ Correspondence: Paolo Agnese, UNINETTUNO University, Rome, Italy.
}

Received: October 21, 2020

Accepted: November 26, 2020

Online Published: December 3, 2020

doi:10.5430/ijba.v12n1p9

URL: https://doi.org/10.5430/ijba.v12n1p9

\begin{abstract}
This paper investigates the impact of unconventional monetary policy (UMP) on bank profitability in the euro area, over the period 2007-2019.

In particular, through multiple regression models, we analyze the relationship between the UMP variables (Longer-term refinancing operations and Securities held for monetary policy purposes) and the main bank profitability variables used in the literature (Return on average equity, Return on average assets and Net interest margin).

This work is original compared to recent studies on the subject as it considers the impact of UMP expressed in terms of volumes rather than in terms of interest rates on bank profitability variables.

Our results suggest that the UMP adopted by the Eurosystem over the period considered is negatively associated with bank profitability expressed by the Return on average equity and the Return on average asset. By contrast, monetary policy measures do not seem to have had any effect on the Net interest margin.
\end{abstract}

Keywords: eurosystem, unconventional monetary policy, bank profitability, bank performance, euro area banks

JEL Classification: E52, E58, G01, G21

\section{Introduction}

Following the global financial crisis that broke out in August 2007, central banks all over the world have adopted extraordinary unprecedented accommodative monetary measures, by lowering official interest rates and adopting a wide range of unconventional monetary policy (UMP), including negative (nominal) interest rates, longer-term refinancing operations and large-scale purchases of financial assets.

The UMP has sparked intense debate about the potential side effects of these measures on the banking system, also with regard to bank profitability (ECB 2016).

The hypothetical adverse impact of UMP on bank profitability has crucial financial stability implications. In fact, low profitability potentially hampers the bank's ability to provide enough credit to the economy. This would affect the resilience of the banking system to adverse shocks that could lead to high costs for bank's stakeholders. In particular, "banks' ability to generate adequate profits is relevant for the sustainability of the banking system and, as such, for its ability to provide adequate funding to the economy" (ECB 2016, p. 69).

Without doubt, bank profitability contributes to banking and financial stability. In fact, an adequate level of profitability is essential for the credit institutions to be able to generate capital internally, as well as to originate loans to the private sector (Altavilla et al. 2018).

The effectiveness of the UMP transmission mechanism is under assessment by the academics and central banks, regarding the ability of the banking industry to provide enough credit to the real economy. All this considering the uncertain effects on banks' profitability.

Therefore, this paper aims to analyze the impact of UMP adopted by the Eurosystem on bank profitability in the euro area, over the period 2007-2019. We do not consider the unconventional measures launched in 2020, in response to the COVID-19 Pandemic, which are still ongoing. 
In order to verify the impact in question, we include the following main bank profitability measures considered in the related literature: Return on equity, Return on asset and Net interest margin.

The remainder of the paper is organized as follows. Section 2 presents the literature review on the impact of monetary policy on bank profitability. In Section 3 we present the models and the data sources utilized. Section 4 shows the empirical results. In Section 5 we summarize the paper and propose some conclusions.

\section{Literature Review}

Monetary policies, standard and non-standard, have played a crucial role in addressing weak macroeconomic performance and in supporting financial and banking systems.

In fact, it should be considered that such measures provide banks with abundant liquidity from monetary authorities and lead to a reduction in the cost of debt with positive consequences for the bank funding and the creditworthiness of the borrowers, thereby supporting bank capital, as well as reducing non-performing loans.

Bank profits are crucial for bank capital and therefore for the financial stability and bank resilience (Altavilla et al. 2018).

Moreover, there may also be downsides associated with UMP, particularly when interest rates remain too-low-for-too-long.

These potential downsides include a reduction in bank profitability which could definitely hamper the transmission of monetary policy.

Therefore, the concrete impact of UMP on bank profitability must be empirically verified, considering whether a protracted period of low or negative interest rates is capable of altering the relationship between monetary measures and bank profitability.

Moreover, monetary policy action specifically affects bank profitability through several channels with an unclear cumulative ex ante impact. On the one hand, monetary policy can lead to lower net interest income and, on the other hand, the monetary policy measures in place ensure that bank funding conditions are significantly eased (ECB 2016).

Recently, part of the literature on the subject denies that UMP has had a seriously adverse effect on bank profitability and the economy through the banking system (Altavilla et al. 2018). Madaschi and Nuevo (2017) show that profitability has continued to improve, even with negative monetary policy rates. Mamatzakis and Bermpei (2016) show that UMP has a negative relationship with bank performance over the period 2007Q2-2013Q2.

However, other authors argue that extraordinarily low interest rates have a negative effect on the banking system. Borio et al. (2017), analyzing the effects of monetary policy on bank profitability after the global financial crisis, find that the impact, on balance, was positive in the first two years post-crisis (2009-10) but turned negative in the following four years (2011-14). They conclude that very low interest rates erode bank profitability. Eggertsson et al. (2019) also show that the introduction of negative rates yields a reduction in bank profitability.

Other studies highlight that the impact of UMP on bank profitability differs significantly between banks and with reference to the geographical areas considered. Claessens et al. (2018) find that low rates weakened bank profitability in the euro area more than Canada and United States. Arseneau (2017) shows that this impact is significantly heterogeneous among banks and much of this heterogeneity can be explained by cross-bank differences in the provision of liquidity services. However, the distributional effects vanish at the aggregate level as liquidity provision is well diversified across all banks. Hofmann et al. (2020) show that the ECB's UMP significantly lowered retail lending and deposit rates in Germany, France, Spain and Italy in particular. The impact on banks' intermediation margins through retail lending-deposit rate spreads is not clear, with significant compressions prevailing only in Germany and Italy.

Furthermore, recent studies argue that profitability has remained essentially unchanged as the positive effects of monetary policy have been almost offset by the negative ones, so the net effect is uncertain.

Eisenschmidt and Smets (2018) show that the zero lower bound constraint is binding for interest rates of bank deposits held by households. Nevertheless, the pass-through to loan rates is unchanged, even with reference to banks that are highly dependent on household deposits. The negative effect on interest rate margin and profitability is generally offset by the positive impact of lower market rates on asset values and loan loss provisions. Jobst and Lin (2016) note that negative interest rates have had a positive effect on the economy so far, helping to lower bank funding costs and boost asset prices. However, interest rate cuts also weigh on bank profitability. Substantial rate cuts may, at some point, outweigh the benefits of higher asset values and stronger aggregate demand. Kumar et al. 
(2020) suggest that an increase in short-term rates leads to an increase in bank profitability, while an increase in long-term interest rates reduces bank profitability. In addition, the capital adequacy ratio has a positive impact on bank profitability, while the non-performing loan ratio and the cost to income ratio have a negative impact on bank profitability. Lopez et al. (2018) examine the effect of negative nominal interest rates on bank profitability. They find that banks experience losses in interest income that are almost fully offset by savings on the cost of deposits and gains in non-interest income, including capital gains on securities and fees. Goodhart and Kabiri (2019), while accept that bank profitability has held up better than might have been expected, argue that this is because banks, in order to protect themselves, have raised the cost of intermediation and allowed a decrease in the quality of their loan portfolio, thereby reducing the beneficial effect of domestic credit expansion.

Finally, some studies empirically point out the lack of connection between UMP and bank profitability.

For example, Kenourgios and Ntaikou (2019) provide evidence that bank lending decisions and the performance of euro area banks are not UMP driven. This implies the ECB's limited ability to enhance the effectiveness of the banks' lending channel and to affect banks' profitability during the global financial crisis.

\section{Methodology}

\subsection{Models Specification}

The variables considered in the statistical models can be classified into four types: bank profitability variables; monetary variables; bank-specific control variables; macroeconomic control variables.

The bank profitability variables are dependent variables while the last three types represent independent variables.

In particular, we consider the ROAE - Return on average equity (Kenourgios and Ntaikou 2019; Kumar et al. 2020; Mamatzakis and Bermpei 2016), the ROAA - Return on average assets (Altavilla et al. 2018; Borio et al. 2017; Goodhart and Kabiri 2019; Kenourgios and Ntaikou 2019; Kumar et al. 2020; Mamatzakis and Bermpei 2016) and the NIM - Net interest margin (Arseneau 2017; Borio et al. 2017; Goodhart and Kabiri 2019; Mamatzakis and Bermpei 2016) as the dependent variables of bank profitability. The ROAE variable (profit or loss after tax divided by average total equity) represents the net income as a percent of average total equity, where the latter excludes the hybrid capital. The ROAA variable (profit or loss after tax divided by average total assets) is equal to net income as a percent of average assets. The NIM variable (net interest income or expense divided by total earning assets) represents the Net interest income as a percent of interest earning assets.

With reference to monetary variables, we consider the following two: the Longer-term refinancing operations (LTRO); the Securities held for monetary policy purposes (SEC). Both variables refer to the annual consolidated balance sheet of the Eurosystem and are expressed in terms of the natural logarithm of the respective volumes. Therefore, in relation to the UMP variables considered, in this paper we analyze the data at an aggregate level (Eurosystem), without distinguishing from country to country. The item "Longer-term refinancing operations" includes two longer-term refinancing operations (with a maturity of 36 months and the option of early repayment after one year) announced on 20 December 2011 and on 28 February 2012, as well as the targeted longer-term refinancing operations (TLTROs), with a maturity of up to 4 years. The TLTROs are targeted operations, as the amount that banks can borrow is linked to their loans to corporates and households. A first series of these operations was announced on 5 June 2014, a second series on 10 March 2016 (TLTRO II) and a third series on 7 March 2019 (TLTRO III). We analyze the period 2007-2019, and then we exclude the Pandemic emergency longer-term refinancing operations (PELTROs), a series of additional longer-term refinancing operations to ensure liquidity to the banking system and smooth money market conditions during the pandemic period.

The item "Securities held for monetary policy purposes" includes, in particular, the "Asset purchase programme (APP)", which was initiated in mid-2014. The APP consists, in turn, of the following programmes: Corporate sector purchase programme (CSPP); Public sector purchase programme (PSPP); Asset-backed securities purchase programme (ABSPP); third Covered bond purchase programme (CBPP3). In this paper we exclude the Pandemic emergency purchase programme (PEPP), a new purchase programme announced on 18 March 2020 in response to the Pandemic emergency.

We also analyze whether banking characteristics influence the transmission of monetary policy measures to bank profitability.

In particular, we consider the following bank-specific control variables: ETA; INT; TCA; COST and SIZE.

The ETA variable is equal to the ratio of total equity to total assets (Borio et al. 2017; Kenourgios and Ntaikou 2019; Klaressen et al. 2017). 
The INT variable is the interbank lending as a percent of interbank borrowings. Securities financing transactions from assets and liabilities are also included in the calculation (Kenourgios and Ntaikou 2019).

The TCA variable is the total capital adequacy ratio on transitional basis (Kumar et al. 2020). It's a measurement of a bank's available capital expressed as a percent of a bank's risk-weighted credit exposures. It's used to protect depositors and promote the stability and efficiency of financial system.

The COST variable is the cost-to-income ratio. It is equal to total operating expenses as a percent of operating revenues and represents a measure of efficiency (Altavilla et al. 2018; Borio et al. 2017; Kumar et al. 2020).

The SIZE variable is the size of bank measured by natural log of total assets (Borio et al. 2017; Mamatzakis and Bermpei 2016).

Furthermore, to capture the general economic conditions, we take into consideration two macroeconomic control variables widely used in the relative literature (Altavilla et al. 2018; Altunbas et al. 2010; Arseneau 2017; Chortareas et al. 2011; Kenourgios and Ntaikou 2019; Kumar et al. 2020; Mamatzakis and Bermpei 2016). In particular, we include the annual euro area GDP and inflation.

The GDP variable indicates the gross domestic product of euro area (Note 1). It is used as a proxy of macroeconomic stability (Borio et al. 2017; Chortareas et al. 2011; Kenourgios and Ntaikou 2019; Mamatzakis and Bermpei 2016). The GDP is an important indicator to assess the country's economy and has a significant impact on every business, including banks (Kenourgios and Ntaikou 2019). GDP is one of the macro factors that can explain the profitability of banks, both statistically and economically (Altavilla et. al 2018).

The INF variable is the inflation expressed by the euro area Harmonised Indices of Consumer Prices (Note 2) (Altavilla et al. 2018).

All variables considered in this work are analyzed through multiple regression models. In particular, we utilize the multiple linear models with and without the fixed effects.

In fact, there may be unobservable values correlated with the explanatory variables and this correlation would lead to a biased estimate. The fixed effects model helps to verify unobserved heterogeneity when this heterogeneity is constant over time. For example, there may be differences between country and country in the performance of banks, in the levels of interest rates, in the prices of real estate market.

We tested whether the fixed effects model is better than the random effects model by using the Hausman test. It showed that individual effects are significantly correlated with at least one regressor in the model and that therefore the random effects model is problematic. Consequently, we preferred the fixed effects model compared to the random effects model.

The underlying hypothesis is that there may be a significant relationship, of linear type, between the independent variables and the dependent variables.

The pooled Ordinary Least Squares (OLS) model to measure the effects of UMP on bank profitability is the following:

$$
\operatorname{Prof}_{i, t}=\beta_{0}+\beta_{1} \operatorname{LTRO}_{t}+\beta_{2} \operatorname{SEC}_{t}+\Phi Z_{i, t}+\Omega X_{t}+u_{i, t}
$$

with:

$\mathrm{i}=1, \ldots, 86$;

$\mathrm{t}=2007, \ldots, 2019$

where:

' $\mathrm{i}$ ' is the cross section unit (bank);

' $\mathrm{t}$ ' is the year;

$\beta_{0}$ is the intercept;

$\beta_{1}, \beta_{2}$ are the coefficients associated with the monetary variables;

$\Phi$ are the coefficients associated with the bank-specific control variables;

$\Omega$ are the coefficients associated with the macroeconomic control variables;

$\mathrm{u}_{\mathrm{i}, \mathrm{t}}$ is the error term or specific disturbance of the i-th unit at time ' $\mathrm{t}$ ';

Prof $f_{i, t}$ is the bank profitability measured by ROAA $A_{i, t}, \operatorname{ROAE}_{i, t}$ and $\mathrm{NIM}_{i, t}$ of the $\mathrm{i}$-th unit at time ' $\mathrm{t}$ '; 
$\mathrm{ROAA}_{\mathrm{i}, \mathrm{t}}$ is the Return on average assets of the $\mathrm{i}$-th unit at time ' $\mathrm{t}$ ';

$\operatorname{ROAE}_{\mathrm{i}, \mathrm{t}}$ is the Return on average equity of the $\mathrm{i}$-th unit at time ' $\mathrm{t}$ ';

$\mathrm{NIM}_{\mathrm{i}, \mathrm{t}}$ is the Net interest margin of the $\mathrm{i}$-th unit at time ' $\mathrm{t}$ ';

$\mathrm{LTRO}_{\mathrm{t}}$ is the natural log of volume of the longer-term refinancing operations at time ' $\mathrm{t}$ ';

$\mathrm{SEC}_{\mathrm{t}}$ is the natural log of volume of the securities held for monetary policy purposes at time ' $\mathrm{t}$ ';

$\mathrm{Z}_{\mathrm{i}, \mathrm{t}}$ are the bank-specific control variables $\left(\mathrm{ETA}_{\mathrm{i}, \mathrm{t}} ;\right.$ Interbank $\left._{\mathrm{i}, \mathrm{t}} ; \mathrm{TCA}_{\mathrm{i}, \mathrm{t}} ; \operatorname{COST}_{\mathrm{i}, \mathrm{t}} ; \operatorname{SIZE}_{\mathrm{i}, \mathrm{t}}\right)$;

$\mathrm{ETA}_{\mathrm{i}, \mathrm{t}}$ is the ratio of total equity to total assets of the $\mathrm{i}$-th unit at time ' $\mathrm{t}$ ';

$\mathrm{INT}_{\mathrm{i}, \mathrm{t}}$ includes all interbank loans and deposits placed with other financial institutions, net of impairment allowance of a bank 'i' at time ' $t$ ';

$\mathrm{TCA}_{\mathrm{i}, \mathrm{t}}$ is the total capital adequacy ratio on transitional basis of the $\mathrm{i}$-th unit at time ' $\mathrm{t}$ ';

$\operatorname{COST}_{\mathrm{i}, \mathrm{t}}$ is the cost-to-income ratio equal to operating cost to total income of the $\mathrm{i}$-th unit at time ' $\mathrm{t}$ ';

$\mathrm{SIZE}_{\mathrm{i}, \mathrm{t}}$ is the size of bank measured by natural $\log$ of total assets of the $\mathrm{i}$-th unit at time ' $\mathrm{t}$ ';

$\mathrm{X}_{\mathrm{t}}$ are the macroeconomic control variables $\mathrm{GDP}_{\mathrm{t}}$ and $\mathrm{INF}_{\mathrm{t}}$;

$\mathrm{GDP}_{\mathrm{t}}$ is the gross domestic product growth rate of the euro area at time ' $\mathrm{t}$ ';

$\mathrm{INF}_{\mathrm{t}}$ is the Harmonised Index of Consumer Prices of the euro area at time ' $\mathrm{t}$ '.

The fixed effects model to measure the effects of UMP on bank profitability is the following:

$$
\operatorname{Prof}_{\mathrm{i}, \mathrm{t}}=\beta_{1} \mathrm{LTRO}_{\mathrm{t}}+\beta_{2} \mathrm{SEC}_{\mathrm{t}}+\Phi \mathrm{Z}_{\mathrm{i}, \mathrm{t}}+\Omega \mathrm{X}_{\mathrm{t}}+\alpha_{\mathrm{i}}+\mathrm{u}_{\mathrm{i}, \mathrm{t}}
$$

where:

$\mathrm{i}=1, \ldots, 86$;

$\mathrm{t}=2007, \ldots, 2019$;

$\alpha_{\mathrm{i}}=$ individual effect, constant over time;

$\mathrm{u}_{\mathrm{i}, \mathrm{t}}=$ residual error term of the $\mathrm{i}$-th unit at time ' $\mathrm{t}$ '.

In summary, the statistical models used relate the dependent variables (profitability) to the independent variables (UMP), in order to assess their type and strength of dependence.

Furthermore, the models include some dimensional control variables (banking and macroeconomic variables). This in order to consider certain balance sheet (equity to assets, total assets, cost-to-income ratio, etc.) and profitability (ROAA, ROAE, Net interest margin) characteristics of the analyzed banks, as well as macroeconomic variables (GDP, inflation) of the euro area.

\subsection{Sample and Data Sources}

The paper focuses over the period 2007-2019, as we analyze the dynamics of UMP adopted by the Eurosystem following the global financial crisis.

Banking data for profitability variables and specific-bank control variables are from Moody's Analytics BankFocus (annual reports of the euro area banks). These data are integrated with the information included in the annual reports of the individual banks published in the institutional websites.

The dataset consists of euro area commercial, cooperative and savings banks active in 2019. Considering that at this level of search strategy is 4,538 banks, we take into account the largest euro area banks by total assets. In particular, we include euro area banks with total assets of at least 10 Billions euros in 2019. Consequently, even by eliminating banks with insufficient data, we have a sample of 86 euro area largest banks active over the period 2007-2019.

Instead, the data relating to monetary policy variables are from the annual consolidated balance sheets of the Eurosystem. The source of this data is the EBC's institutional website (Note 3).

The data of the macroeconomic variables are from "Eurostat Database" (Note 4).

The descriptive statistics for the variables used in the estimation are reported in Table 1.

For each variable, Table 1 shows mean, median, range, measures of central tendency and some selected percentiles describing the frequency distribution of the data. The standard deviation, coefficient of variation, skewness, kurtosis are available for each variable. 
Table 1. Descriptive statistics

\begin{tabular}{|c|c|c|c|c|}
\hline Variable & Mean & Median & Min & Max \\
\hline \multicolumn{5}{|c|}{ Profitability variable } \\
\hline ROAE & -0.1151 & 6.1696 & -981.61 & 82.251 \\
\hline ROAA & 0.2410 & 0.3345 & -12.380 & 6.4147 \\
\hline NIM & 1.7807 & 1.6050 & -1.8607 & 6.4963 \\
\hline \multicolumn{5}{|c|}{ Monetary variable } \\
\hline LTRO & 13.244 & 13.331 & 12.501 & 13.851 \\
\hline SEC & 13.088 & 12.532 & 10.268 & 14.791 \\
\hline \multicolumn{5}{|c|}{ Bank control variable } \\
\hline ETA & 6.8428 & 6.3024 & -3.9012 & 61.104 \\
\hline COST & 62.823 & 62.458 & -1512.0 & 2333.5 \\
\hline $\begin{array}{l}\text { SIZE } \\
\end{array}$ & 10.987 & 10.864 & 9.7235 & 12.429 \\
\hline $\begin{array}{l}\text { INT } \\
\end{array}$ & 136.49 & 58.779 & 1.1576 & 42685 \\
\hline TCA & 15.244 & 14.600 & -5.0000 & 43.820 \\
\hline \multicolumn{5}{|c|}{ Macroeconomics variable } \\
\hline$\overline{\text { GDP }}$ & 103.75 & 102.10 & 97.9000 & 112.20 \\
\hline INF & 1.4782 & 1.5333 & 0.1833 & 3.2833 \\
\hline Variable & Standard Dev. & Coeff. of var. & Skewness & Kurtosis \\
\hline \multicolumn{5}{|c|}{ Profitability variable } \\
\hline ROAE & 45.969 & 399.34 & -13.262 & 229.29 \\
\hline$\overline{\text { ROAA }}$ & 1.2616 & 5.2350 & -4.4784 & 38.281 \\
\hline NIM & 0.9498 & 0.53340 & 0.92210 & 1.9752 \\
\hline \multicolumn{5}{|c|}{ Monetary variable } \\
\hline LTRO & 0.3551 & 0.02682 & -0.6855 & 0.02050 \\
\hline SEC & 1.3976 & 0.1068 & -0.3289 & -0.7954 \\
\hline \multicolumn{5}{|c|}{ Bank control variable } \\
\hline$\overline{\text { ETA }}$ & 4.2647 & 0.62324 & 4.1443 & 35.871 \\
\hline$\overline{\text { COST }}$ & 106.40 & 1.6937 & 4.0878 & 264.28 \\
\hline SIZE & 0.6549 & 0.05961 & 0.2822 & -0.9112 \\
\hline INT & 1323.3 & 9.6951 & 30.246 & 958.28 \\
\hline TCA & 4.8760 & 0.31987 & 1.4466 & 5.4061 \\
\hline \multicolumn{5}{|c|}{ Macroeconomics variable } \\
\hline GDP & 4.2049 & 0.0405 & 0.7579 & -0.6205 \\
\hline$\overline{I N F}$ & 0.9660 & 0.6535 & 0.1906 & -1.0105 \\
\hline Variable & 5\% Perc. & 95\% Perc. & $\begin{array}{l}\text { Interquartile } \\
\text { range }\end{array}$ & $\begin{array}{l}\text { Missing } \\
\text { observations }\end{array}$ \\
\hline
\end{tabular}




\begin{tabular}{lllll}
\hline ROAE & -24.693 & 16.946 & 7.4250 & 0 \\
\hline ROAA & -1.2524 & 1.4048 & 0.4955 & 0 \\
\hline NIM & 0.5987 & 3.6151 & 1.0844 & 0 \\
\hline Monetary variable & & & & \\
\hline LTRO & 12.501 & 13.851 & 0.3969 & 0 \\
\hline SEC & 10.268 & 14.791 & 2.3964 & 172 \\
\hline Bank control variable & & & & 0 \\
\hline ETA & 2.3923 & 13.127 & 3.6420 & 0 \\
\hline COST & 41.019 & 92.342 & 16.668 & 0 \\
\hline SIZE & 10.036 & 12.130 & 1.0752 & 0 \\
\hline INT & 8.5032 & 255.52 & 70.681 & 0 \\
\hline TCA & 9.5000 & 23.410 & 5.2100 & 0 \\
\hline Macroeconomics variable & & & & 0 \\
\hline GDP & 97.900 & 112.20 & 5.3000 & 1.6833 \\
\hline INF & 0.1833 & 3.2833 & & 0 \\
\hline
\end{tabular}

Note: Data covering the period Q1 2007 - Q4 2019 but SEC data covering the period Q3 2009 - Q4 2019.

Sources: our own calculations on Moody's Analytics BankFocus database, ECB Statistical Data Warehouse, Eurostat Database.

The distribution between the percentiles shows wide variation of the data in the sample. This variation is visible for all variables in the table. For the TCA variable, for example, the interquartile range is about $9.5 \%$ to $23 \%$.

Descriptive statistics indicate that the mean of ROAA is $0.241 \%$, with a standard deviation of 1.2616 , while the mean of ROAE is $-0.115 \%$ with a standard deviation of 45.969 . There is a relatively large variation in ROAE compared to ROAA. Among the profitability variables, ROAE shows a wide range of variation, ranging from a minimum of -981.61 to a maximum of 82.25 . This range is largely plausible considering the period of financial turbulence and the large time period of the analyzed sample.

With reference to monetary variables, however, the range of variation is limited. This is also confirmed by volatility measures such as standard deviation and coefficient of variation.

As regards the banks control variables, the cost to income ratio (COST), which measures the degree of operational efficiency, has a wide range of variation (min $-1,512.0$ and $\max 2,333.5$ ).

Macroeconomic variables (GDP and INF), on the other hand, show a fair degree of stability.

The total number of observations available for each variable is 1,118 with the exception of SEC variable and Net loan variable.

The SEC variable has 172 missing observations because it represents a measure of UMP adopted by the Eurosystem since July 2009. In this case the number of observations is equal to 946.

Table 2 indicates the correlation matrix between variables and shows a heterogeneous relationship between monetary and profitability variables.

In fact, the LTRO variable shows a negative correlation with all profitability variables, while the SEC variable indicates a positive relation with ROAE and ROAA variables. Therefore, the descriptive statistics show an unclear relationship between monetary policy measures and the profitability of euro area banks.

Moreover, the matrix does not indicate the cause and effect relationship but only the dynamics between the variables. In effect, it does not show whether monetary variables cause changes in the banks' profitability or vice versa. Therefore, it's necessary to carry out the analysis through statistical regression tools.

The banking control variables do not indicate a relevant correlation between them. 
With reference to macroeconomic variables, the correlations that emerge from Table 2 are those consistent with economic theory. In fact, GDP is positively correlated with bank profitability variables (ROAA and ROAE) and INF is negatively correlated with the same profitability variables. Furthermore, the GDP variable shows a high correlation with the SEC variable (0.9356).

Table 2. Correlation matrix

\begin{tabular}{|c|c|c|c|c|c|c|c|c|c|c|c|c|}
\hline ROAE & ROAA & NIM & LTRO & SEC & ETA & COST & SIZE & INT & TCA & GDP & INF & \\
\hline \multirow[t]{11}{*}{1.0000} & 0.6731 & 0.0103 & -0.1384 & 0.0759 & 0.1861 & 0.0209 & 0.0012 & 0.0091 & 0.1709 & 0.0887 & -0.1009 & ROAE \\
\hline & 1.0000 & 0.0460 & -0.1440 & 0.1150 & 0.2677 & -0.0111 & -0.0528 & 0.0110 & 0.2255 & 0.1315 & -0.0761 & ROAA \\
\hline & & 1.0000 & -0.0006 & -0.0757 & 0.2051 & -0.0394 & -0.1077 & 0.0037 & -0.1339 & -0.0614 & 0.0120 & NIM \\
\hline & & & 1,0000 & 0.1961 & 0.0343 & 0.0407 & 0.0058 & 0.0077 & 0.1556 & 0.2208 & 0.1771 & LTRO \\
\hline & & & & 1.0000 & 0.1760 & 0.0167 & -0.0053 & 0.0372 & 0.3624 & 0.9356 & 0.0538 & SEC \\
\hline & & & & & 1.0000 & 0.0488 & -0.3991 & -0.0061 & 0.3670 & 0.1785 & -0.1384 & ETA \\
\hline & & & & & & 1.0000 & 0.0009 & 0.0033 & 0.0368 & 0.0104 & 0.0055 & COST \\
\hline & & & & & & & 1.0000 & -0.0436 & -0.0718 & -0.0013 & 0.0077 & SIZE \\
\hline & & & & & & & & 1.0000 & 0.0195 & 0.0430 & 0.0164 & INT \\
\hline & & & & & & & & & 1.0000 & 0.3652 & -0.2084 & TCA \\
\hline & & & & & & & & & & 1.0000 & -0.0701 & GDP \\
\hline
\end{tabular}

Note: Critical value at $5 \%$ (for two tails) $=0.0587$ for $n=1116$.

\section{Empirical Results}

In this section we examine the impacts of UMP on banks' profitability and whether these effects are influenced by individual bank characteristics and macroeconomic environment.

Table 3 shows the results of four ROAE regressions on monetary variables. In particular, in columns 1 and 2 the pooled OLS model is applied, while in columns 3 and 4 the fixed effects model is applied. Columns 2 and 4 consider the complete sample from 2007 to 2019 by omitting the SEC variable as there is no data before 2009. Consequently, the observations considered in the regressions with both monetary variables are 946, while the observations considered in the regressions without SEC variable are 1,118.

It can be noted that the fixed effects model fits the data better than the pooled OLS model in terms of both $\mathrm{R}^{2}$ and $\mathrm{R}^{2}$ adjusted.

The models appear appropriate with stable coefficients.

In all four regressions, LTRO and SEC variables are highly significant and show a negative relationship with the bank profitability expressed by the ROAE. This means that such monetary policy measures have a significant negative effect on bank profitability. 
Table 3. ROAE regressions on monetary variables

\begin{tabular}{|c|c|c|c|c|}
\hline & \multicolumn{4}{|c|}{ Econometric model } \\
\hline & \multicolumn{2}{|l|}{ Pooled OLS } & \multicolumn{2}{|l|}{ Fixed effects } \\
\hline & (1) & (2) & (3) & (4) \\
\hline \multirow[t]{2}{*}{ Constant } & -34.0009 & $146.6650 * *$ & & \\
\hline & (95.9014) & $(60.4027)$ & & \\
\hline \multirow[t]{2}{*}{ LTRO } & $-5.5424 * * *$ & $-22.1994 * * *$ & $-15.3299 * * *$ & $-24.1611 * * *$ \\
\hline & (5.6614) & $(3.9300)$ & (5.1723) & $(3.7061)$ \\
\hline \multirow[t]{2}{*}{$\overline{\mathrm{SEC}}$} & $-5.5424 *$ & & $-6.8168 * *$ & \\
\hline & (3.1343) & & $(2.8754)$ & \\
\hline \multirow[t]{2}{*}{$\overline{\text { ETA }}$} & $1.7995 * * *$ & $1.8012 * * *$ & $6.2517 * * *$ & $4.7930 * * *$ \\
\hline & $(0.4169)$ & $(0.3667)$ & $(0.6857)$ & $(0.5704)$ \\
\hline \multirow[t]{2}{*}{$\overline{\mathrm{COST}}$} & 0.0080 & 0.0064 & -0.0108 & -0.0121 \\
\hline & $(0.0148)$ & $(0.0125)$ & $(0.0148)$ & $(0.0125)$ \\
\hline \multirow[t]{2}{*}{$\begin{array}{l}\text { SIZE } \\
\end{array}$} & $6.3242 * *$ & $5.4840 * *$ & $87.0802 * * *$ & $48.5370 * * *$ \\
\hline & $(2.5926)$ & $(2.2196)$ & $(17.1543)$ & $(10.4767)$ \\
\hline \multirow[t]{2}{*}{ INT } & 0.0004 & 0.0004 & 0.0007 & 0.0005 \\
\hline & $(0.0011)$ & $(0.0010)$ & $(0.0011)$ & $(0.0010)$ \\
\hline \multirow[t]{2}{*}{ TCA } & $1.5884 * * *$ & $1.1132 * * *$ & $2.3391 * * *$ & $1.5723 * * *$ \\
\hline & $(0.3728)$ & $(0.3162)$ & $(0.4935)$ & $(0.4156)$ \\
\hline \multirow[t]{2}{*}{ GDP } & $2.0142 * *$ & 0.5649 & 1.3678 & -0.0959 \\
\hline & $(0.9723)$ & $(0.3449)$ & (0.8938) & $(0.3438)$ \\
\hline \multirow[t]{2}{*}{ INF } & $-4.6754 * *$ & -0.9423 & -2.6480 & 1.1858 \\
\hline & $(2.0438)$ & (1.4392) & (1.8874) & (1.3883) \\
\hline Observations & 946 & 1118 & 946 & 1118 \\
\hline$\overline{R^{2}}$ & 0.097015 & 0.082035 & 0.316118 & 0.261697 \\
\hline$R^{2}$ adjusted & 0.088332 & 0.075413 & 0.181287 & 0.135815 \\
\hline
\end{tabular}

\section{Note:}

The asterisks denote the significance level of the coefficients at $10 \%(*), 5 \%(* *)$ and $1 \%(* * *)$.

The number of observations for ROAE variable is lower in regressions (1) and (3) than in regressions (2) and (4), considering that SEC data are available for the period Q3 2009 - Q4 2019.

The output of the fixed effects regressions does not generate any intercept since in this model the intercept appears to be different for each bank.

On the other hand, the measure expressed by the COST variable does not have a statistically significant impact on the profitability measures analyzed.

An important aspect of banks' financial structure, as depicted by the TCA variable, is captured in our analysis. The Total capital adequacy ratio is positively correlated with the ROAE in the 2007-2019 periods (Kumar et al. 2020). This finding probably suggests that banks have increased their solidity in forecasting economic growth prospects.

The level of bank capitalization, expressed by equity to assets ratio (ETA), is positively correlated to ROAE variable. This suggests that the confidence expressed by banks investors amid the financial uncertainty that dominated the 2007-2019 periods was awarded with higher return on assets.

In all regressions, both macroeconomic control variables (GDP and INF) are used but they are not overall significant. 
The GDP variable expressed in regression (1) has a positive and statistically significant impact on the profitability of the euro area banks. Moreover, the relationship (negative) between ROAE and INF variables is significant only in the regression (1).

This finding implies the considerable importance of economic growth on the ROAE variable of banks.

Table 4 shows the outputs of four ROAA regressions on monetary variables.

Similar to the results of ROAE regressions, LTRO and SEC monetary policy variables are negatively correlated with the ROAA in all regressions.

Table 4. ROAA regressions on monetary variables

\begin{tabular}{|c|c|c|c|c|}
\hline & \multicolumn{4}{|c|}{ Econometric model } \\
\hline & \multicolumn{2}{|c|}{ Pooled OLS } & \multicolumn{2}{|l|}{ Fixed effects } \\
\hline & (1) & (2) & (3) & (4) \\
\hline \multirow[t]{2}{*}{ Constant } & -2.8558 & $4.7954 * * *$ & & \\
\hline & $(2.5334)$ & $(1.6135)$ & & \\
\hline \multirow[t]{2}{*}{ LTRO } & $-0.4001 * * *$ & $-0.6996^{* * *}$ & $-0.4108 * * *$ & $-0.7470 * * *$ \\
\hline & $(0.1496)$ & $(0.1050)$ & $(0.1331)$ & $(0.0977)$ \\
\hline \multirow[t]{2}{*}{$\overline{\mathrm{SEC}}$} & $-0.2352 * * *$ & & $-0.2705 * * *$ & \\
\hline & $(0.0828)$ & & $(0.0740)$ & \\
\hline \multirow[t]{2}{*}{$\overline{\text { ETA }}$} & $0.0585 * * *$ & $0.0680 * * *$ & $0.1417 * * *$ & $0.1191 * * *$ \\
\hline & $(0.0110)$ & $(0.0098)$ & $(0.0176)$ & $(0.0150)$ \\
\hline \multirow[t]{2}{*}{$\mathrm{COST}$} & -0.0004 & -0.0002 & -0.0002 & -0.0002 \\
\hline & $(0.0004)$ & $(0.0003)$ & $(0.0004)$ & $(0.0003)$ \\
\hline \multirow[t]{2}{*}{ SIZE } & 0.1138 & $0.1015 *$ & $1.4063 * * *$ & $0.8559 * * *$ \\
\hline & $(0.0685)$ & $(0.0593)$ & $(0.4414)$ & $(0.2762)$ \\
\hline \multirow[t]{2}{*}{ INT } & $6.47695 \mathrm{e}-06$ & $9.06997 \mathrm{e}-06$ & $2.19015 \mathrm{e}-05$ & $2.11025 \mathrm{e}-05$ \\
\hline & $(2.89965 \mathrm{e}-05)$ & $(2.67702 \mathrm{e}-05)$ & $(2.72135 \mathrm{e}-05)$ & $(2.58567 \mathrm{e}-05)$ \\
\hline \multirow[t]{2}{*}{ TCA } & $0.0589 * * *$ & $0.0396 * * *$ & $0.0823 * * *$ & $0.0528 * * *$ \\
\hline & $(0.0098)$ & $(0.0084)$ & $(0.0127)$ & $(0.0110)$ \\
\hline \multirow[t]{2}{*}{$\overline{\mathrm{GDP}}$} & $0.0863 * * *$ & $0.0240 * * *$ & $0.0739 * * *$ & 0.0105 \\
\hline & $(0.0257)$ & $(0.0092)$ & $(0.0230)$ & $(0.0091)$ \\
\hline \multirow[t]{2}{*}{ INF } & $-0.0869 * * *$ & 0.0352 & -0.0421 & $0.0770 * *$ \\
\hline & $(0.0540)$ & $(0.0384)$ & $(0.0486)$ & $(0.0366)$ \\
\hline Observations & 946 & 1118 & 946 & 1118 \\
\hline$\overline{R^{2}}$ & 0.142967 & 0.130336 & 0.384257 & 0.318503 \\
\hline$R^{2}$ adjusted & 0.134726 & 0.124063 & 0.206640 & 0.156870 \\
\hline
\end{tabular}

Note:

The asterisks denote the significance level of the coefficients at $10 \%(*), 5 \%(* *)$ and $1 \%(* * *)$.

The number of observations for ROAA variable is lower in regressions (1) and (3) than in regressions (2) and (4), considering that SEC data are available for the period Q3 2009 - Q4 2019.

The output of the fixed effects regressions does not generate any intercept since in this model the intercept appears to be different for each bank. 
The considerations expressed for the ROAE are also valid for the ROAA regressions with reference to both ETA and TCA variables. The regressions in Table 4 show that macroeconomic variables have a negative and statistically significant impact on ROAA.

The GDP variable has a more significant positive relationship with ROAA than with ROAE while the type of relationship with the INF variable is not highlighted as it has the opposite sign in regressions (1) and (4) where it is significant.

Table 5 presents the results of regressions (pooled OLS and fixed effects models) with reference to the Net interest margin (NIM) on monetary policy in the euro area.

Only the SEC monetary variable has a significant and negative effect on NIM, possibly due to low (or negative) market interest rates. When market interest rates are low, banks' revenues from loans decrease while banks' interest expenses from deposits do not decrease to the same extent, as banks' portfolio mainly consists of deposits (Kenourgios and Ntaikou 2019). The four regressions expressed in Table 5 show that the LTRO variable does not have a significant relationship with NIM variable.

The SIZE variable has an ambiguous effect on NIM variable. The relationship is not significant in the Pooled OLS model while the relationship is negative in the case of the fixed effects model (columns 3 and 4).

The negative relationship between TCA and bank profitability is also confirmed in the case of NIM variable.

Regarding the macroeconomic variables, in the output of the regressions expressed in column (4) only GDP has a significant and negative relation with NIM variable.

Table 5. NIM regressions on monetary variables

\begin{tabular}{|c|c|c|c|c|}
\hline & \multicolumn{4}{|c|}{ Econometric model } \\
\hline & \multicolumn{2}{|c|}{ Pooled OLS } & \multicolumn{2}{|l|}{ Fixed effects } \\
\hline & (1) & (2) & (3) & (4) \\
\hline \multirow[t]{2}{*}{ Constant } & 0.8789 & 2.0132 & & \\
\hline & $(1.7753)$ & $(1.2375)$ & & \\
\hline \multirow[t]{2}{*}{ LTRO } & 0.0215 & 0.0842 & 0.0011 & 0.0384 \\
\hline & $(0.1048)$ & $(0.0805)$ & $(0.0452)$ & $(0.0387)$ \\
\hline \multirow[t]{2}{*}{ SEC } & -0.0569 & & $-0.0596 * *$ & \\
\hline & $(0.0580)$ & & $(0.0251)$ & \\
\hline \multirow[t]{2}{*}{$\overline{\text { ETA }}$} & $0.0617 * * *$ & $0.0651 * * *$ & -0.0091 & 0.0038 \\
\hline & $(0.0077)$ & $(0.0075)$ & $(0.0060)$ & $(0.0060)$ \\
\hline \multirow[t]{2}{*}{$\overline{\mathrm{COST}}$} & -0.0003 & -0.0004 & $-0.0003 *$ & $-0.0003 * *$ \\
\hline & $(0.0003)$ & $(0.0003)$ & $(0.0001)$ & $(0.0001)$ \\
\hline \multirow[t]{2}{*}{ SIZE } & 0.0494 & -0.0211 & $-0.5932 * * *$ & $-0.2320 * *$ \\
\hline & $(0.0480)$ & $(0.0455)$ & $(0.1498)$ & $(0.1094)$ \\
\hline \multirow[t]{2}{*}{ INT } & $-4.49144 \mathrm{e}-06$ & $7.49695 \mathrm{e}-06$ & $2.64825 \mathrm{e}-06$ & $1.21847 \mathrm{e}-05$ \\
\hline & $(2.03194 \mathrm{e}-05)$ & $(2.05320 \mathrm{e}-05)$ & $(9.23473 \mathrm{e}-06)$ & $(1.02371 \mathrm{e}-05)$ \\
\hline \multirow[t]{2}{*}{ TCA } & $-0.0494 * * *$ & $-0.0458 * * *$ & $-0.0091 * *$ & $-0.0078^{*}$ \\
\hline & $(0.0069)$ & $(0.0065)$ & $(0.0043)$ & $(0.0043)$ \\
\hline \multirow[t]{2}{*}{$\overline{\text { GDP }}$} & 0.0113 & -0.0081 & 0.0084 & $-0.0123 * * *$ \\
\hline & $(0.0180)$ & $(0.0071)$ & $(0.0078)$ & $(0.0036)$ \\
\hline \multirow[t]{2}{*}{ INF } & -0.0033 & 0.0011 & -0.0066 & 0.0060 \\
\hline & $(0.0378)$ & $(0.0295)$ & $(0.0165)$ & $(0.0145)$ \\
\hline
\end{tabular}




\begin{tabular}{cllll}
\hline Observations & 946 & 1118 & 946 & 1118 \\
\hline$R^{2}$ & 0.095421 & 0.097433 & 0.847596 & 0.811530 \\
\hline$R^{2}$ adjusted & 0.086723 & 0.090922 & 0.063501 & 0.037878 \\
\hline
\end{tabular}

Note:

The asterisks denote the significance level of the coefficients at $10 \%(*), 5 \%(* *)$ and $1 \%(* * *)$.

The number of observations for NIM variable is lower in regressions (1) and (3) than in regressions (2) and (4), considering that SEC data are available for the period Q3 2009 - Q4 2019.

The output of the fixed effects regressions does not generate any intercept since in this model the intercept appears to be different for each bank.

\section{Conclusions}

Through statistical analysis based on multiple linear regressions (pooled OLS and fixed effects models), in this paper we analyze the implications of UMP adopted by the Eurosystem (Longer-term refinancing operations and Securities held for monetary policy purposes) on significant bank profitability variables (Return on average equity, Return on average assets and Net interest margin) in the euro area over 2007-2019 period. To this end, in our analysis we use the main bank-specific control variables considered in the literature to determine statistically solid results. We also include some macroeconomic control variables (GDP and Inflation), in order to reflect the influence of the macroeconomic environment on banks' profitability.

This represents an interesting case study as it includes the heterogeneity of a sample of large banks operating in different countries within a monetary union.

This research shows the presence of a certain influence of UMP on bank profitability variables analyzed.

In particular, the results of the regressions suggest that monetary policy measures had a significant impact on banks' profitability over the period 2007-2019 and that this relationship is inverse.

The greater the volume of liquidity provided by the Eurosystem through the UMP considered (Longer-term refinancing operations and Securities held for monetary policy purposes), the lower the profitability of the euro area banks expressed in terms of Return on average equity and Return on average assets.

As for the profitability variable expressed by the Net interest margin, it does not show a solid relationship with the Securities held for monetary policy purposes variable and it does not seem to have any connection with the Longer-term refinancing operations variable. Our results are consistent with what has been demonstrated from some recent literature (Borio et al. 2017; Claessens et al. 2018; Eggertsson et al. 2019), although the latter focus on interest rates, while our research considers the impact of UMP expressed in terms of volumes.

This paper aims to take a step forward in studying the effects of monetary policy measures on banks' profitability compared to the related literature, as unlike the latter, monetary policy variables have been considered in terms of stocks rather than of interest rates.

However, this study considers monetary variables at an aggregate level (Eurosystem level), although part of the recent literature shows that the effects of UMP can differ from country to country (Arseneau 2017; Claessens et al. 2018; Hofmann et al. 2020).

Therefore, starting from the results of this research, an interesting hypothesis for a future study could be to verify whether the relationship between UMP and bank profitability demonstrated at the aggregate level shows differences between the countries of the euro area.

\section{References}

Altavilla, C., Bouncinha, M., \& Peydro, J. (2018). Monetary policy and bank profitability in a low interest rate environment. Economic Policy, 33(96), 531-586.

Altunbas, Y., Gambacorta, L., \& Marques-Ibanez, D. (2010). Does monetary policy affect bank risk-taking? Bank for International Settlements. Working Paper n. 298, 17 March 2010.

Arseneau, D. M. (2017). How Would Us Banks Fare in a Negative Interest Rate Environment?. Board of Governors of the Federal Reserve System Research Series. 
Chortareas, G., Girarardone, C., \& Ventouri, A. (2011). Bank supervision, regulation, and efficiency: evidence from the European Union. Journal of Financial Stability, 8, 292-302.

Claessens, S., Coleman, N., \& Donnelly, M. (2018). "Low-For-Long” interest rates and banks' interest margins and profitability: Cross-country evidence. Journal of Financial Intermediation, 35, 1-16.

Eggertsson, G. B., Juelsrud, R. E., Summers, L. H., \& Wold, E. G. (2019). Negative Nominal Interest Rates and the Bank Lending Channel. National Bureau of Economic Research. Working Paper Series n. 25416, January 2019.

Eisenschmidt, L., \& Smets, F. (2018). Negative interest rates: lessons from the euro area. Central Banking, Analysis, and Economic Policies Book Series. In A. Álvaro, B. Markus, \& S. Diego (Eds.), Monetary policy and financial stability: transmission mechanisms and policy implications (pp. 13-42). Central Bank of Chile.

European Central Bank. (2016). Financial Stability Review, November 2016.

Goodhart, C. A. E., \& Kabiri, A. (2019). Monetary policy and bank profitability in a low interest rate environment: a follow-up and a rejoinder. CEPR Discussion papers n. 13752. Centre for Economic Policy Research (CEPR), London, UK.

Hofmann, B., Illes, A., Lombardi, M. J., \& Mizen, P. (2020). The impact of unconventional monetary policies on retail lending and deposit rates in the euro area bank for international settlements. BIS Working Paper n. 850, 31 March 2020.

Jobst, A., \& Lin, H. (2016). Negative Interest Rate Policy (NIRP): Implications for monetary transmission and bank profitability in the euro area. International Monetary Fund. IMF Working Papers n. WP/16/172, August 2016.

Kenourgios, D., \& Ntaikou, D. (2019). ECB's unconventional monetary policy and bank lending supply and performance in the euro area. Journal of Economics and Finance. https://doi.org/10.1007/s12197-019-09503-6.

Kumar, V., Acharya, S., \& Ho, L. T. H. (2020). Does Monetary Policy Influence the Profitability of Banks in New Zealand?. International Journal of Financial Studies, 8(35).

Lopez, J. A., Rose, A. K., \& Spiegel, M. M. (2018). Why Have Negative Nominal Interest Rates Had Such a Small Effect on Bank Performance? Cross Country Evidence. National Bureau of Economics Research. NBER Working Paper n. 25004. September 2018.

Madaschi, C., \& Nuevo, I. P. (2017). The profitability of banks in a context of negative monetary policy rates: the cases of Sweden and Denmark. European Central Bank. Occasional Paper Series n. 195/August 2017.

Mamatzakis, E., \& Bermpei, T. (2016). What is the effect of unconventional monetary policy on bank performance?. Journal of International Money and Finance, 67, 239-263.

\section{Notes}

Note 1. https://ec.europa.eu/eurostat/databrowser/product/page/NAMA_10_GDP_custom_9312.

Note 2. https://ec.europa.eu/eurostat/databrowser/product/page/EI_CPHI_M.

Note 3. https://www.ecb.europa.eu/pub/annual/balance/html/index.en.html.

Note 4. https://ec.europa.eu/eurostat/data/database.

\section{Copyrights}

Copyright for this article is retained by the author(s), with first publication rights granted to the journal.

This is an open-access article distributed under the terms and conditions of the Creative Commons Attribution license (http://creativecommons.org/licenses/by/4.0/). 